Al-Adzka: Jurnal Ilmiah Pendidikan Guru Madrasah Ibtidaiyah

p-ISSN: 2088-9801 I e-ISSN: 2597-937X

Vol. 9, No. 2 (Desember 2019), Hal. 99 - 106

\title{
ANALISIS ADVERSITY QUOTIENT MAHASISWA PGMI DALAM MENGATASI MASALAH
}

\author{
Rahmawati \\ Prodi Pendidikan Guru Madrasah Ibtidaiyah \\ Pascasarjana Universitas Islam Negeri Sunan Kalijaga \\ Jl. Marsda Adisucipto Yogyakarta, Indonesia \\ E-mail: rahmazahra2705@gmail.com
}

Website: https://jurnal.uin-antasari.ac.id/index.php/adzka

Received: 10 Juli 2019; Accepted: 10 Januari 2020; Published: 12 Januari 2019

\begin{abstract}
This study aims to analyze the level of Adversity Qoutient of PGMI students at the State Islamic University of Antasari Banjarmasin. This research is field research. The study population was PGMI students, while the study sample was 15\% (104 students). This research method is quantitative. Data collection by distributing Adversity Qoutient scale questionnaires. After the data collected was categorized, the assessment and interpretation were then analyzed descriptively. Based on the results of research and analysis of interpretation of data regarding the analysis of the AQ level of PGMI students at a very high level of $9,61 \%$ (10 subjects), high AQ is $83,65 \%$ ( 87 subjects), the remaining level of the low Adversity Qoutient level is 6,73\% (7 subjects) and no subject has the Adversity Qoutient in the very low category. Overall it can be concluded that most of the research subjects have high Adversity Qoutient, meaning that most research subject have a high ability to survive and overcome the difficulties and challenges of life faced.
\end{abstract}

Keywords: adversity quotient; PGMI students; to solve problem.

\begin{abstract}
ABSTRAK
Penelitian ini bertujuan untuk menganalisis tingkat Adversity Quotient mahasiswa PGMI Universitas Islam Negeri Antasari Banjarmasin. Penelitian ini adalah penelitian lapangan. Populasi penelitian ini adalah mahasiswa PGMI, sedangkan sampel penelitian adalah $15 \%$ (104 mahasiswa). Metode penelitian ini adalah metode kuantitatif. Pengumpulan data dengan mendistribusikan kuesioner skala Adversity Quotient. Setelah data terkumpul dilakukan kategorisasi, penilaian dan interpretasi kemudian dianalisis secara deskriptif. Berdasarkan hasil penelitian dan analisis interpretasi data mengenai analisis tingkat $A Q$ mahasiswa PGMI berada pada tingkat yang sangat tinggi yaitu 9,61\% (10 subjek), $A Q$ yang tinggi adalah 83,65\% (87 subjek), level yang tersisa dari tingkat Adversity Quotient rendah adalah 6,73\% (7 subjek) dan tidak ada subjek yang memiliki Adversity Quotient dalam kategori sangat rendah. Secara keseluruhan dapat disimpulkan bahwa sebagian besar subjek penelitian memiliki Adversity Quotient yang tinggi, artinya sebagian besar subjek penelitian memiliki kemampuan tinggi untuk bertahan dan mengatasi kesulitan dan tantangan hidup yang dihadapi.
\end{abstract}

Kata Kunci : adversity quotient; mahasiswa PGMI; mengatasi masalah 



\section{PENDAHULUAN}

Keberhasilan individu dipengaruhi oleh beberapa faktor. Awalnya banyak pendapat yang menyatakan bahwa keberhasilan belajar individu tergantung pada Intelligence Quotient $(I Q)$. Kecerdasan yang terukur secara ilmiah dan dipengaruhi oleh faktor keturunan ini telah lama dianggap oleh para orang tua, guru, dan pengusaha sebagai peramal kesuksesan. Namun, dunia ini sudah penuh dengan contoh orang yang memiliki $I Q$ tinggi tapi tidak mewujudkan potensinya. Maka dari itu sukses tidak hanya ditentukan dengan memiliki $I Q$ yang tinggi.(Stoltz, , 2000: 14). Goleman dan Stoltz memperkenalkan gagasan baru mengenai kecerdasan. Selain IQ, kita semua memiliki Emotional Quotient (EQ) (Stoltz, 2000: 15). EQ tidak hanya sekedar kemampuan untuk mengendalikan emosi dalam kaitannya dengan hubungan sosial tetapi juga dalam kaitannya dengan pemenuhan psikofisik. Dikatakan bahwa dengan memiliki emosional yang baik maka seseorang akan memiliki kompetensi pribadi dan kompetensi sosial yang baik.

Secara ringkas Stoltz mendefinisikan $A Q$ sebagai kemampuan seseorang dalam mengamati kesulitan dan mengolah kesulitan tersebut dengan kecerdasan yang dimiliki sehingga menjadi sebuah tantangan untuk menyelesaikannya. Terutama dalam pencapaian sebuah tujuan, cita-cita, harapan dan yang paling penting adalah kepuasan pribadi dari hasil kerja/aktifitas itu sendiri (Diana, 2008:15). Kecerdasan Adversity pertama kali diperkenalkan oleh Paul G. Stoltz yang disusun berdasarkan hasil riset lebih dari 500 kajian diseluruh dunia. Menurut Stoltz dan sekaligus pelopor study Adversity Quotient ini, Adversity Quotient adalah kegigihan dalam mengatasi segala rintangan dalam mencapai puncak sukses yang diinginkan". Hal ini juga selaras dengan pendapat Agustian, "Adversity Quotient adalah kecerdasan yang dimiliki seseorang dalam mengatasi kesulitan dan bertahan hidup". Secara sederhana Adversity Quotient didefinisikan sebagai kecerdasan yang dimiliki individu dalam menghadapi kesulitan-kesulitan, hambatan-hambatan maupun tantangan dalam hidup"(Supardi U.S: 65). Kemampuan remaja dalam menghadapi masalah-masalah hidup inilah yang oleh Stoltz disebut dengan Adversity Quotient (Nailul Fauziah, 2014: 7892).

Kecerdasan mengatasi masalah atau Adversity Quotient (AQ). $A Q$ adalah sebuah kemampuan seseorang dalam mengamati kesulitan dan mengubah kesulitan tersebut menjadi sebuah tantangan untuk menyelesaikannya. Sebuah kecerdasan yang dikenal dengan istilah Adversity Quotient atau disingkat $A Q$. $A Q$ merupakan faktor penentu keberhasilan. Perannya merupakan gabungan antara $I Q$ dan $E Q$, ini menggambarkan bahwa untuk bisa menjadi pribadi yang berhasil tidak cukup hanya dengan mengandalkan kemampuan intelektual atau hanya mengandalkan kecerdasan emosional semata melainkan perlu menggabungkan keduanya (Miarti Yoga, 2016: 26).

Berikut sebuah ilustrasi yang bisa dicerna yang menggambarkan hubungan antara $A Q, E Q$ dan $I Q$.

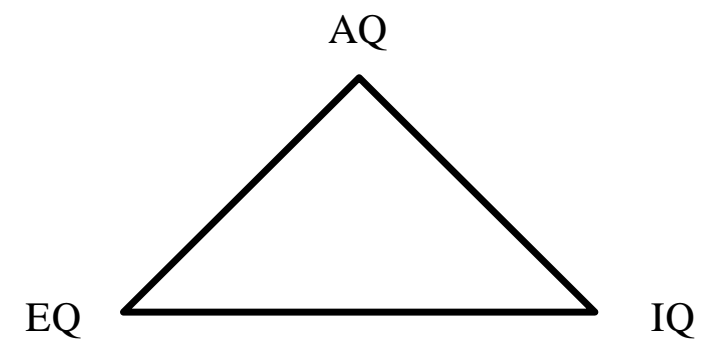

Gambar 1. Hubungan antara AQ, EQ, dan IQ

$A Q$ merupakan faktor penentu kesuksesan yang salah satu komponennya adalah ketekunan dan daya juang. Selain itu, $A Q$ juga merupakan perpaduan antara $I Q$ dan $E Q$ sehingga bisa membentuk seseorang untuk lebih berdaya, produktif dan matang dalam berbagai 
pertimbangan. Jadi $A Q, I Q$ dan $E Q$ merupakan tiga pilar yang saling bersangkutan (Miarti Yoga, 2016:26). Stoltz mengelompokkan tiga jenis kepribadian manusia yang bisa menggambarkan kemampuan $A Q$. Dengan mengelompokkan ini, seseorang bisa dinilai apakah memiliki $A Q$ tinggi, biasa-biasa saja, sangat rendah, atau bahkan tidak memiliki sama sekali.

Stoltz menjelaskan bahwa dalam menjalani kehidupan, manusia dapat dibagi atas tiga kategori, yakni: quitter (diam dan dinamis), camper (selalu mencoba tetapi gampang menyerah setelah mendapat tantangan) dan climber (orang yang berani dan bertahan menghadapi tantangan kehidupan). Kesuksesan menurut Stoltz ibarat puncak gunung tertinggi yang mampu didaki oleh manusia. Orang sukses adalah mereka yang mau dan mampu mendaki/memanjat (climb) hingga kepuncak gunung. Inilah yang termasuk kategori orang climber atau pendaki. Climber adalah seorang pemikir yang berpikir bahwa tidak akan ada hambatan untuk dirinya bisa sukses walaupun itu umur, usia, ras, cacat fisik, atau mental atau hambatan lainnya, seorang climber juga memikirkan segala kemungkinankemungkinan (Eky Abdul Razak, 2016:24).

\section{A. Dimensi Adversity Quotient}

$\mathrm{C}$ adalah singkatan dari "control" atau kendali. C mempertanyakan: Berapa banyak kendali yang anda rasakan terhadap sebuah peristiwa yang menimbulkan kesulitan? Kata kuncinya adalah merasakan. O merupakan kependekan dari "origin" (asal-usul) dan "ownership" (pengakuan). $\mathrm{O}_{2}$ mempertanyakan dua hal: Siapa atau apa yang menjadi asalusul kesulitan? Dan sampai sejauh manakah saya mengakui akibat-akibat kesulitan itu?. Dimensi R ini mempertanyakan: Sejauh manakah kesulitan akan menjangkau bagianbagian lain dari kehidupan saya? Respons-respons dengan $A Q$ akan membuat kesulitan merembes ke segi-segi lain dari kehidupan seseorang. Daya Tahan/Endurance (E). E atau Endurance (daya tahan) adalah dimensi terakhir pada $A Q$. Dimensi ini mempertanyakan dua hal yang berkaitan: Berapa lamakah kesulitan akan berlangsung? dan Berapa lamakah penyebab kesulitan itu akan berlangsung? semakin rendah skor $E$ yang dimiliki maka semakin besar kemungkinan-kemungkinan individu menganggap kesulitan dan penyebabpenyebabnya akan berlangsung lama, kalau bukan selama-lamanya (Paul G. Stoltz, PhD, 2002: 141- 162).

\section{B. Faktor -faktor Pembentuk Kecerdasan Adversity Quotient \\ 1. Daya Saing}

Kecerdasan Adversity yang rendah dikarenakan tidak adanya daya saing ketika menghadapi kesulitan, sehingga kehilangan kemampuan untuk menciptakan peluang dalam kesulitan yang dihadapi (Eky Abdul Razak, 2016:46).

2. Produktivitas

Produktivitas disini yaitu adanya korelasi yang positif antara kinerja seseorang dengan respon yang diberikan terhadap kesulitan. Artinya respon konstruktif yang diberikan seseorang terhadap kesulitan akan membantu meningkatkan kinerja lebih baik dan sebaliknya respons yang destruktif mempunyai kinerja yang rendah.

\section{Motivasi}

Motivasi yang kuat mampu menciptakan peluang dalam kesulitan, artinya seseorang dengan motivasi yang kuat akan berupaya menyesuaikan kesulitan dengan menggunakan segenap kemampuan menurut penelitian Stoltz.

3. Mengambil Resiko

Seseorang yang mempunyai kecerdasan Adversity tinggi lebih berani mengambil resiko dari tindakan yang dilakukan, hal itu dikarenakan seseorang dengan kecerdasan Adversity tinggi 
merespon kesulitan secara lebih konstruktif. Resiko merupakan aspek esensial pendakian (Eky Abdul Razak, 2016:46).

4. Perbaikan

Seseorang dengan kecerdasan Adversity yang tinggi senantiasa berupaya mengatasi kesulitan dengan langkah konkrit, orang-orang yang, memiliki $A Q$ lebih tinggi menjadi lebih baik, sedangkan orang-orang yang memiliki $A Q$ nya lebih rendah menjadi lebih buruk (Eky Abdul Razak, 2016:47).

5. Ketekunan

Ketekunan merupakan inti pendakian dan $A Q$ seseorang. Ketekunan adalah kemampuan untuk terus-menerus berusaha, bahkan manakala dihadapkan pada kemunduran-kemunduran atau kegagalan. Seligman menemukan bahwa seseorang yang merespon kesulitan dengan baik akan senantiasa bertahan. Mereka yang responsnya buruk ketika berhadapan dengan kesulitan akan mudah menyerah. $A Q$ menentukan keuletan yang dibutuhkan untuk bertekun (Paul G. Stoltz, 2002:95).

6. Belajar

Menurut Carol Dweck, membuktikan bahwa anak-anak yang merespon secara optimis akan banyak belajar dan lebih berprestasi dibandingkan dengan anak- anak yang memiliki pola pesimistis (Eky Abdul Razak, 2016:46).

Adversity Quotient dalam Islam adalah kemampuan individu untuk mempersepsikan kesulitan dan mengubahnya menggunakan kecerdasan yang dimiliki sehingga menjadi peluang menuju kesuksesan. Adapun dimensi AQ dalam islam antara lain diwujudkan berupa kesabaran ketika menghadapi kesulitan, tanggung jawab serta tindakan nyata untuk menghadapi masalah, kekuatan dan usaha (ihtiyar) serta harapan (do'a) untuk menunjukkan optimis dalam menghadapi masalah (DM. Sesanti, 2018:35). Berdasarkan dari penjelasan diatas yang menyatakan peranan Adversity Quotient yang dapat menentukan kesuksesan dan kegagalan seorang individu dalam menjalani masa remajanya dan masa perkembangan selanjutnya, maka peneliti merasa tertarik untuk melihat analisis tingkat Adversity Quotient $(A Q)$ mahasiswa PGMI dalam mengatasi masalah.

\section{METODE PENELITIAN}

Jenis Penelitian ini adalah penelitian lapangan (field research). Pendekatan penelitian ini adalah pendekatan kuantitatif. Peneliti hanya akan mengambil sampel dari masing-masing tingkatan menggunakan teknik proportional random sampling. Populasi dalam penelitian ini adalah mahasiswa PGMI, yaitu populasi dari tiga tingkatan yaitu angkatan tahun 2017 berjumlah 249 terdiri dari 58 laki-laki dan 191 perempuan, angkatan tahun 2016 berjumlah 247 terdiri dari 59 laki-laki dan 188 perempuan, angkatan 2015 berjumlah 198 terdiri dari 47 laki-laki dan 151 perempuan. Total jumlah semua dari tiga tingkatan adalah 694., namun hanya diambil 104 mahasiswa. Teknik pengumpulan data menggunakan kuesionair yang disebarkan pada sampel yang telah ditentukan. Kemudian, data yang diperoleh dianalisis secara deskriptif berdasarkan kategori di bawah ini.

Tabel 1. Rumus Norma Kategorisasi Adversity Quotient

\begin{tabular}{ccc}
\hline No. & Kategorisasi & Rumus Norma \\
\hline 1. & Sangat Tinggi & $>3,25-4,0$ \\
\hline 2. & Tinggi & $>2,5-3,25$ \\
\hline 3. & Rendah & $>1,75-2,5$ \\
\hline 4. & Sangat Rendah & $1-1,75$ \\
\hline
\end{tabular}




\section{HASIL DAN PEMBAHASAN}

\section{A. Hasil Penelitian}

Subjek penelitian ini adalah mahasiswa PGMI Fakultas Tarbiyah dan Keguruan UIN Antasari Banjarmasin angkatan 2015, angkatan 2016 dan angkatan 2017. Semuanya berjumlah 104 mahasiswa (diambil sampel 15\%).

Tabel. 2. Distribusi Aspek Adversity Quotient dalam Frekuensi

\begin{tabular}{cccc}
\hline No. & Aspek $\boldsymbol{A Q}$ & Frekuensi Absolut & Frekuensi Relatif (\%) \\
\hline 1 & Control & 9 & $31,03 \%$ \\
\hline 2 & Origin \& Ownership & 5 & $17,24 \%$ \\
\hline 3 & Reach & 9 & $31,03 \%$ \\
\hline 4 & Endurance & 6 & $20,69 \%$ \\
\hline & Jumlah & $\mathbf{2 9}$ & $\mathbf{1 0 0 \%}$ \\
\hline
\end{tabular}

1. Kategorisasi Aspek Adversity Quotient

a) Aspek Control

Berdasarkan hasil penelitian diketahui bahwa 3 mahasiswa memiliki aspek control yang rendah, 67 mahasiswa memiliki aspek control yang tinggi dan 34 mahasiswa memiliki aspek control yang sangat tinggi. Hasil penelitian diatas menunjukkan bahwa sebagian besar subjek penelitian mempunyai skor control tinggi dan sangat tinggi, artinya sebagian besar subjek merasakan kendali yang besar terhadap peristiwa-peristiwa yang menimbulkan kesulitan. Semakin besar kendali yang dirasakan akan membawa ke pendekatan yang lebih berdaya dan proaktif. Kendali yang tinggi memiliki implikasi-implikasi yang jangkauannya jauh dan positif, serta sangat bermanfaat untuk kinerja, produktivitas, dan kesehatan dalam jangka panjang. Semakin tinggi skor control subjek semakin besar kemungkinannya bertahan menghadapi kesulitan-kesulitan dan tetap teguh dalam niat serta lincah dalam pendekatan mencari suatu penyelesaian.

b) Aspek Origin dan Ownership

Berdasarkan hasil penelitian diketahui bahwa 5 mahasiswa memiliki aspek Origin dan Ownership yang sangat rendah, 38 mahasiswa memiliki Origin dan Ownership aspek yang rendah, 54 mahasiswa memiliki aspek Origin dan Ownership yang tinggi dan 7 mahasiswa memiliki aspek Origin dan Ownership yang sangat tinggi. Hasil penelitian diatas menunjukkan bahwa Origin dan ownership terbagi cukup merata namun diantara keduanya sebagian besar subjek penelitian memiliki Origin dan ownership yang tinggi, hal ini berarti subjek penelitian mempunyai kemampuan untuk menghindari perilaku menyalahkan diri sendiri yang tidak perlu sambil menempatkan tanggung jawab sendiri pada tempatnya yang tepat.

Leon Festinger adalah seorang penganut psikologi kognitif yang menjelaskan bahwa berpikir dan membuat keputusan adalah proses kognitif dan inilah yang menentukan perilaku seseorang yang menjadi pembentuk kepribadian. Hal ini setara dengan yang dijelaskan pada Adversity Quotient dalam dimensi Origin dan ownership.

c) Aspek Reach

Berdasarkan hasil penelitian diketahui bahwa 13 mahasiswa memiliki aspek reach yang rendah, 80 mahasiswa memiliki aspek reach yang tinggi dan 11 mahasiswa memiliki aspek reach yang sangat tinggi. Hasil penelitian diatas menunjukkan bahwa reach yang cukup tinggi. Semakin tinggi skor reach, semakin besar kemungkinannya membatasi jangkauan masalahnya pada peristiwa yang sedang dihadapi. Sedangkan, semakin rendah skor reach semakin besar kemungkinan menganggap bahwa peristiwa-peristiwa buruk sebagai bencana, dengan membiarkannya meluas, seraya menyedot kebahagiaan dan ketenangan pikiran saat prosesnya berlangsung. 


\section{d) Aspek Endurance}

Berdasarkan hasil penelitian diketahui bahwa 1 mahasiswa memiliki aspek endurance yang sangat rendah, 25 mahasiswa memiliki aspek endurance yang rendah, 54 mahasiswa memiliki aspek endurance yang tinggi dan 24 mahasiswa memiliki aspek endurance yang sangat tinggi. E atau Endurance adalah dimensi terakhir pada $A Q$. Hasil penelitian diatas menunjukkan bahwa subjek penelitian terbagi rata namun sebagian besar subjek penelitian mempunyai skor Endurance yang tinggi, artinya subjek memandang kesulitan dan penyebab-penyebabnya sebagai sesuatu yang bersifat sementara, cepat berlalu dan kecil kemungkinannya terjadi lagi. Hal ini akan meningkatkan energi, optimisme dan kemungkinan untuk bertindak. Prof. Dr. Howard Gardner seorang psikolog berpendapat ada 8 area kecerdasan. Salah satunya adalah cerdas paham diri yaitu kemampuan untuk menganalisis atau memahami diri sendiri dan bertindak berdasarkan pemahaman tersebut. Termasuk didalamnya mengetahui kekuatan dan kelemahan diri dan suasana hati dan keinginan diri. Ini sesuai dengan teori dari Adversity Quotient.

2. Adversity Quotient Mahasiswa PGMI (laki-laki dan perempuan)

a) Adversity Quotient Mahasiswa PGMI Laki-Laki

Sejumlah 104 mahasiswa yang menjadi subjek penelitian diantaranya ada 27 mahasiswa yang berjenis kelamin laki-laki, yang tersebar dari tiga tingkatan yaitu 2015 sejumlah 9 orang, 2016 sejumlah 10 orang dan 2017 sejumlah 8 orang. Hasil penelitian menunjukkan bahwa dari 27 mahasiswa memiliki tingkat $A Q$ yang rendah 5 orang dan yang tinggi 22 orang.

Dari sebaran 27 orang angkatan 2015 yang berjumah 9 orang terdiri dari 1 orang mahasiswa dalam kategori $A Q$ rendah yaitu dengan nilai 2,4, sedangkan 8 mahasiswa dalam kategori $A Q$ tinggi dengan rentang nilai dari 2,5 hingga 3,2. Dari angkatan 2016 yang berjumah 10 orang terdiri dari 1 orang mahasiswa dalam kategori $A Q$ rendah yaitu dengan nilai 2,2, sedangkan 9 mahasiswa dalam kategori $A Q$ tinggi dengan rentang nilai dari 2,6 hingga 3,0. Dari angkatan 2017 yang berjumah 8 orang terdiri dari 3 orang mahasiswa dalam kategori $A Q$ rendah yaitu dengan nilai 2,5 , sedangkan 5 mahasiswa dalam kategori $A Q$ tinggi dengan rentang nilai dari 2,6 hingga 2,9.

Penelitian Adversity Quotient mahasiswa PGMI laki-laki memiliki dua kategori yaitu rendah dan tinggi. Mahasiswa yang memiliki Adversity Quotient yang tinggi sudah mampu menunjukkan mereka optimis dalam menghadapi masalah ataupun tantangan. Dijelaskan bahwa Adversity Quotient individu menjadi rendah disebabkan belajar salah (rasa tidak berdaya yang dipelajari).

b) Adversity Quotient Mahasiswa PGMI Perempuan

Sejumlah 104 mahasiswa yang menjadi subjek penelitian diantaranya ada 77 mahasiswa yang berjenis kelamin perempuan, yang tersebar dari tiga tingkatan yaitu 2015 sejumlah 25 orang, 2016 sejumlah 24 orang dan 2017 sejumlah 28 orang. Hasil penelitian menunjukkan bahwa dari 77 mahasiswa memiliki tingkat $A Q$ yang rendah 2 orang, tinggi 65 orang dan sangat tinggi 10 orang. Dari sebaran 77 orang angkatan 2015 yang berjumah 25 orang terdiri dari 20 orang mahasiswa dalam kategori $A Q$ tinggi yaitu dengan nilai 2,7 hingga 3,1, sedangkan 5 mahasiswa dalam kategori $A Q$ sangat tinggi dengan rentang nilai dari 3,3 hingga 3,8. Dari angkatan 2016 yang berjumah 24 orang terdiri dari 2 orang mahasiswa dalam kategori $A Q$ rendah yaitu dengan nilai 2,3, sedangkan 21 mahasiswa dalam kategori $A Q$ tinggi dengan rentang nilai dari 2,6 hingga 3,1, dan 1 orang mahasiswa daalam kategori $A Q$ sangat tinggi dengan nilai 3,3. Dari angkatan 2017 yang berjumah 28 orang terdiri dari 24 orang mahasiswa dalam kategori $A Q$ tinggi yaitu dengan rentang nilai 2,6 hingga 3,1, sedangkan 4 mahasiswa dalam kategori $A Q$ sangat tinggi dengan rentang nilai dari 3,3 hingga 3,4 . 
Dari penelitian kedua jenis kelamin laki laki dan perempuan dapat disimpulkan bahwa perempuan memiliki $A Q$ yang lebih tinggi dari laki-laki itu dapat dilihat bahwa ada mahasiswa perempuan yang memiliki Adversity Quotient kategori sangat tinggi. Mahasiswa yang memiliki $A Q$ yang tinggi ini berarti memiliki daya juang dalam mendapatkan hasil yang diinginkan yaitu prestasi tinggi. Adversity Quotient adalah kemampuan seseorang dalam berjuang menghadapi dan mengatasi masalah, hambatan atau kesulitan yang dimilikinya serta akan mengubahnya menjadi peluang keberhasilan dan kesuksesan. Maka apabila Adversity Quotient ini dimiliki oleh seorang mahasiswa, maka ia akan lebih terdorong mencapai prestasi atau mengarahkan dirinya pada hasil terbaik dengan upaya optimal memanfaatkan peluang, aktif bertindak, termasuk untuk belajar secara mandiri.

c) Adversity Quotient Mahasiswa PGMI Angkatan 2015, 2016 dan 2017

1) Adversity Quotient Mahasiswa PGMI Angkatan 2015

Mahasiswa PGMI angkatan 2015 memiliki $A Q$ rendah sebanyak 1 orang yang memiliki nilai 2,4 , sedangkan yang memiliki $A Q$ tinggi sebanyak 28 orang yang memiliki rentang nilai dari 2,6 hingga 3,1 dan mahasiswa yang memiliki $A Q$ sangat tinggi sebanyak 5 orang yang memiliki rentang nilai dari 3,3 hingga 3,8. Diketahui bahwa mahasiswa PGMI angkatan 2015 memiliki nilai $A Q$ paling rendah 2,4 dan nilai yang paling tinggi 3,8.

2) Adversity Quotient Mahasiswa PGMI Angkatan 2016

Mahasiswa PGMI angkatan 2016 memiliki $A Q$ rendah sebanyak 3 orang yang memiliki nilai 2,2 hingga 2,4 sedangkan yang memiliki $A Q$ tinggi sebanyak 30 orang yang memiliki rentang nilai dari 2,6 hingga 3,1 dan mahasiswa yang memiliki $A Q$ sangat tinggi sebanyak 1 orang yang memiliki nilai 3,3. Diketahui bahwa mahasiswa PGMI angkatan 2016 memiliki nilai $A Q$ paling rendah 2,2 dan nilai yang paling tinggi 3,3.

3) Adversity Quotient Mahasiswa PGMI Angkatan 2017

Mahasiswa PGMI angkatan 2017 memiliki $A Q$ rendah sebanyak 3 orang yang memiliki nilai 2,5 , sedangkan yang memiliki $A Q$ tinggi sebanyak 29 orang yang memiliki rentang nilai dari 2,6 sampai 3,2 dan mahasiswa yang memiliki $A Q$ sangat tinggi sebanyak 4 orang yang memiliki rentang nilai dari 3,3 sampai 3,4. Diketahui bahwa mahasiswa PGMI angkatan 2017 memiliki nilai $A Q$ paling rendah 2,5 dan nilai yang paling tinggi 3,4.

4) Hasil Adversity Quotient Mahasiswa PGMI

Tabel 3. Distribusi Kategorisasi Data Adversity Quotient

\begin{tabular}{|c|c|c|c|c|}
\hline Variabel & Rentang Nilai & Katagori & Jumlah Subjek & Presentase \\
\hline \multirow{4}{*}{$A Q$} & $>3,25-4,0$ & Sangat tinggi & 10 & $9,61 \%$ \\
\hline & $>2,5-3,25$ & Tinggi & 87 & $83,65 \%$ \\
\hline & $>1,75-2,5$ & Rendah & 7 & $6,73 \%$ \\
\hline & $1-1,75$ & Sangat rendah & - & - \\
\hline
\end{tabular}

Berdasarkan hasil kategori pada tabel tersebut, maka didapat hasil sebanyak 6,73\% Adversity Quotient mahasiswa PGMI yang menjadi subjek penelitian berada dalam kategori rendah, 83,65\% berada pada tingkat kategori tinggi dan 9,61\% Adversity Quotient mahasiswa berada pada tingkat sangat tinggi. Diketahui bahwa Adversity Quotient mahasiswa PGMI dominan pada tingkat tinggi.

\section{B. Pembahasan}

Secara keseluruhan dapat disimpulkan bahwa sebagian besar subjek penelitian memiliki Adversity Quotient yang tinggi, artinya sebagian besar subjek penelitian memiliki kemampuan tinggi dalam bertahan dan mengatasi kesulitan serta tantangan hidup yang dihadapi. Penelitian menunjukkan bahwa ada tiga kategori rendah, tinggi dan sangat tinggi. Lebih besar mahasiswa pada dalam kategori tinggi menuju kategori sangat tinggi itu berarti Camper. Camper adalah orang atau mahasiswa yang cepat puas terhadap hasil yang 
diperoleh meskipun jika lebih berusaha lagi akan memperoleh hasil yang lebih baik. Sehingga perlu didorong untuk lebih meningkatkan usahanya.

\section{PENUTUP}

Berdasarkan hasil penelitian dan analisis interpretasi data mengenai kecenderungan tingkat Adversity Quotient mahasiswa PGMI berada pada tingkat sangat tinggi sebanyak 9,61\% (10 subjek), Adversity Quotient tingkat tinggi sebanyak 83,65\% (87 subjek), sisanya tingkat Adversity Quotient rendah sebanyak 6,73\% (7 subjek) dan tidak ada subjek yang mempunyai Adversity Quotient dalam kategori sangat rendah.

\section{DAFTAR PUSTAKA}

Diana, Nida'U, Study Deskriptif tentang Adversity Quotient pada Siswa Kelas Akselarasi di Sekolah Menengah Atas Negeri 1 Malang (SMA N 1 MALANG), Skripsi. Fakultas Psikologi, UIN Malang, 2008.

Mujahadah, Islam dan Adversity Quotient, Online tersedia di http://menjadihebat.blogspot.co.id/2011/05/islam-dan-adversity-quotient.html

Muslim ibn Al Hajjaj Abu al Hasan al Qusyayri an Naisaburi, shahih Muslim, juz 4 (Bairut: Dar al ihya at Turast al Arabiy, t.th), 2002.

Nailul, Fauziah, Empati, Persahabatan, dan Kecerdasan Adversitas Pada Mahasiswa yang sedang Skripsi. Jurnal Fakultas Psikologi, Universitas Diponegoro. Vo; 13. No.1 April 2014, 78-92.

Razak, Eky Abdul, Pengaruh Prestasi kerja dan kecerdasan Adversity terhadap Proesionalitas Guru Madrasah Ibtidaiyah Se-kota Bogor Jawa Barat, Skripsi. IAIN Surakarta, Surakarta 2016.

Sesanti, DM. Hubungan Antara 16 Tipe Kepribadian Carl Gustaf Jung terhadap Adversity Quotient Mahasiswa, Tesis, UIN Malang, http://etheses.uinmalang.ac.id/2251/6/08410095_Bab_2.pdf

Stoltz, PhD, Paul G, Adversity Quotient: Mengubah Hambatan Menjadi Peluang. Terjemahan: T. Hermaya. Jakarta: Gramedia Widiasarana Indonesia, 2000.

Supardi. U.S, Pengaruh Adversity Quotient terhadap Prestasi belajar Matematika, Skripsi, Universitas Indraprasta, Jakarta Selatan, 2008.

Yoga, Miarti, Adversity Quotient. Solo: Tinta Medina, 2016. 
Analisis Adversity Quetiont Mahasiswa ... 